В. М. Запорожан, В. О. Ульянов, О. О. Тарабрін, О. С. Суслов, Д. С. Сажин Одеський національний медичний університет

\title{
ЄВРОПЕЙСЬКІ СТАНДАРТИ ОСВІТИ В СИМУЛЯЦІЙНІЙ МЕДИЦИНІ. ДОСВІД ОДЕСЬКОГО НАЦІОНАЛЬНОГО МЕДИЧНОГО УНІВЕРСИТЕТУ
}

\author{
V. M. Zaporozhan, V. O. Ulyanov, O. O. Tarabrin, O. S. Suslov, D. S. Sazhyn \\ Odesa National Medical University \\ EUROPEAN STANDARDS OF EDUCATION IN SIMULATION MEDICINE. \\ EXPERIENCE OF THE ODESA NATIONAL MEDICAL UNIVERSITY
}

\begin{abstract}
Мета роботи - висвітлити досвід Одеського національного медичного університету в галузі симуляційної медицини.
Основна частина. В січні 2014 року на базі Одеського національного медичного університету було створено перший на території України Навчально-інноваційний центр практичної підготовки лікаря, з найсучаснішим обладнанням, аналогів якому не існує в країні. В навчанні використовуються такі методики, як моделювання сценаріїв різного рівня складності, гібридна симуляція, “стандартизований пацієнт” та ін. Центр координує свою роботу з провідними у світі центрами симуляційних технологій навчання і по праву претендує на статус базового для підвищення навичок, кваліфікації та перепідготовки лікарів з усіх регіонів України.

Висновки. Основним завданням сучасної середньої, вищої і післядипломної медичної освіти є створення умов для розвитку в учнів широкого спектра компетенцій і міцно закріплених практичних навичок без ризику нанесення шкоди пацієнту. Якраз такі цілі і ставить перед собою симуляційна медицина, яка отримала особливо активний розвиток в останні роки.

Ключові слова: симуляційна медицина; медична освіта; студенти; інтерни; лікарі.

The aim of the work - to highlight the experience of the Odesa National Medical University in the field of simulation medicine.

The main body. In January 2014, on the basis of the Odesa National Medical University, the first in Ukraine Educational-Innovation Center of Practical Training of a Doctor was created on the territory of Ukraine, with the most modern equipment, analogues which do not exist in the country. The training uses techniques such as modeling scenarios of different difficulty levels, hybrid simulation, "standardized patient", etc. The Center coordinates its work with the world's leading centers of simulation training technology and rightly claims to be a basic status for improving skills, qualifications and retraining of doctors from all regions of Ukraine.

Conclusions. The main task of modern secondary, higher and postgraduate medical education is to create conditions for students to develop a wide range of competences and firmly fixed practical skills without risking harm to the patient. Just these goals set forth a simulation medicine, which has been particularly active in recent years.
\end{abstract}

Key words: simulation medicine; medical education; students; interns; doctors.

Вступ. Сучасний світ високотехнологічної медицини висуває підвищені вимоги до якості надання медичних послуг. Якість медичної допомоги, а також якість життя пацієнтів лежать в основі оцінки як професійної діяльності лікарів і медичних установ, так і рівня охорони здоров’я взагалі.

Мета роботи - висвітлити досвід Одеського національного медичного університету в галузі симуляційної медицини.

Основна частина. Останнім часом в Україні відбувається стрімке впровадження великої кількості віртуальних технологій у різні сфери діяльності

(c) В. М. Запорожан, В. О. Ульянов, О. О. Тарабрін та ін. людини. В системі вітчизняної охорони здоров’я, в числі іншого, з' явилися і широко впроваджуються різноманітні фантоми, моделі, муляжі, тренажери, віртуальні симулятори та інші технічні засоби навчання, що дозволяють з тією чи іншою мірою достовірності моделювати процеси, ситуації та інші аспекти професійної діяльності медичних працівників.

Симуляційне навчання не є панацеєю від усіх проблем вітчизняної охорони здоров’я в цілому i медичної освіти зокрема. Але при цьому воно $є$ дієвим і ефективним інструментом для вирішення певних завдань. Для того щоб ці технології принес- 
ли максимальну користь, необхідно чітко визначити їхні переваги і недоліки, після чого поставити цілі і сформулювати завдання, вирішення яких без цих технологій неможливе або недоцільне.

Переваги симуляційного тренінгу:

- клінічний досвід у віртуальному середовищі без ризику для пацієнта;

- об’єктивна оцінка досягнутого рівня майстерності;

- необмежена кількість повторів для відпрацювань навичок;

- відпрацювання дій при рідкісних та таких, що загрожують життю, патологіях;

- частину функцій викладача бере на себе віртуальний тренажер;

- знижений стрес під час перших самостійних маніпуляцій;

- тренінг відбувається незалежно від розкладу роботи клініки;

- розвиток як індивідуальних умінь і навичок, так і здатності командної взаємодії.

Важливим кроком у розвитку медичних симуляторів стала розробка на початку 80-х років математичних моделей фізіологічних процесів серцево-судинної і дихальної систем і їх взаємодія 3 лікарськими речовинами. Математика описувала не тільки статичну картину, але і послідовні зміни, що відбуваються в людському організмі при розвитку патології, корекції патологічного стану фармакологічними препаратами і проведення реанімаційних заходів. Моделювання фізіологічних процесів в організмі людини стало передумовою до створення роботів-пацієнтів, прототипи яких незалежно один від одного розробляли дві групи американських дослідників.

Модернізація галузі охорони здоров’я, постійне підвищення вимог до якості медичної допомоги населенню потребують від лікарів досконального володіння не тільки теоретичною базою, але й практичним досвідом. Для цього існує ряд перешкод - це і неможливість відтворення більшості практичних маніпуляцій, відсутність тематичних пацієнтів, етико-деонтологічні, морально-етичні та законодавчі обмеження у взаєминах між студентами та пацієнтами. Тому найважливішими завданнями сучасної медичної освіти є створення умов для якісної підготовки висококваліфікованих спеціалістів у різних медичних галузях, відпрацювання та закріплення практичних навичок без ризику заподіяння шкоди пацієнту і розвиток здатності швидко приймати рішення та бездоганно виконувати більшість маніпуляцій і втручань. У зв’язку з цим впровадження симуляційного методу навчання як одного із базисних, широкий спектр тренажерів для відпрацювання практичних навичок із високим рівнем реалістичності, віртуальне моделювання різноманітних клінічних ситуацій являє собою нове спрямування в сучасній вітчизняній школі для підготовки висококваліфікованих медичних кадрів вищої та середньої ланок.

У січні 2014 року на базі Одеського національного медичного університету було створено перший на території України Навчально-інноваційний центр практичної підготовки лікаря, з найсучаснішим обладнанням, аналогів якому не існує в країні. В навчанні використовуються такі методики, як моделювання сценаріїв різного рівня складності, гібридна симуляція, “стандартизований пацієнт” та ін. Центр координує свою роботу з провідними у світі центрами симуляційних технологій навчання і по праву претендує на статус базового для підвищення навичок, кваліфікації та перепідготовки лікарів з усіх регіонів України. Метою цього мультидисциплінарного центру є високоякісна професійна підготовка фахівців різних галузей згідно із вимогами практичної охорони здоров'я.

На базі центру відкрита перша в Україні кафедра симуляційної медицини. Згідно з покладеною на неї метою та для її реалізації було визначено чотири основні завдання, а саме:

1. Підвищення якості підготовки фахівців на основі інноваційних організаційних форм, методів навчання та контролю.

2. Науково-методичний супровід системи навчання та оцінки компетентності різних категорій медичних та немедичних працівників.

3. Науково-дослідницька діяльність у сфері симуляційного навчання.

4. Апробація та розробка інноваційних технологій у галузі медичної освіти.

Категорії осіб, що навчаються в центрі: до осіб, які можуть навчатися в центрі, належать студенти вищих або середніх закладів медичної освіти, лікарі-інтерни, магістранти, лікарі-ординатори, аспіранти, практикуючі лікарі, і робітники закладів охорони здоров’я, медичні сестри, фельдшери, акушери, немедичні працівники (співробітники служб цивільного захисту, члени рятувальних команд, військовослужбовці, охоронці, пожежники, моряки, робітники поліції тощо). За два останні роки у центрі пройшли навчання близько 1000 лікарів-курсантів різних спеціальностей і 5000 студентів та інтернів. 
Фахівцями центру розроблені курси тематичного удосконалення та передатестаційні цикли з багатьох спеціальностей, таких, як акушерство і гінекологія, хірургія, неонатологія, анестезіологія, педіатрія, пульмонологія, ендоскопія, кардіологія, медицина невідкладних станів, офтальмологія та ін. Розроблені спеціальні робочі програми з невідкладної кваліфікованої долікарської та лікарської допомоги (для лікарів та працівників середньої медичної ланки).

Особливе місце займає підготовка лікарів для надання кваліфікованої медичної допомоги в зоні бойових дій: з цією метою розроблено спеціальний курс, що дозволяє оперативно перепідготувати лікарів як у центрі, так і за допомогою виїзної бази центру в польові госпіталі. Розроблені спеціальні робочі програми по невідкладній кваліфікованій долікарській та лікарській допомозі у військових умовах, для лікарів та середнього медичного персоналу. Також розроблений курс по невідкладних станах для осіб, що не мають спеціальної медичної освіти (співробітники служб цивільного захисту, члени рятувальних команд, військовослужбовці, охоронці, пожежники, моряки, робітники міліції, водії тощо).

\section{Список літератури}

1. Горшков М. Д. Классификация симуляционного оборудования / М. Д. Горшков, А. В. Федоров // Виртуальные технологии в медицине. - 2012. - № 2 (8). C. 23-35.

2. Abrahamson S. Effectiveness of a simulator in training anesthesiology residents / S. Abrahamson, J. S. Denson, R. M. Wolf // Qual Saf Health Care. - 2004. - No. 13 (5). P. 395-399.

3. Мещерякова М. А. Обучение профессиональным мануальным умениям и оценка уровня их сформированности у студентов медицинских вузов / М. А. Мещеря-

\section{References}

1. Gorshkov, M.D., \& Fedorov, A.V. (2012). Klassifikatsiya simulyatsionnogo oborudovaniya [Classification of simulation equipment]. Virtualnye tekhnologii v meditsine Virtual Technologies in Medicine, 2 (8), 23-35 [in Russian].

2. Abrahamson, S., Denson, J.S., \& Wolf, R.M. (2004). Effectiveness of a simulator in training anesthesiology residents. Qual. Saf. Health Care, 13 (5), 395-397.

3. Meshcheryakova, M.A., Podchernyaeva, N.S., \& Shubina, L.B. (2007). Obuchenie professionalnym manualnym umeniyam i otsenka urovnya ikh sformirovannosti u studentov meditsinskikh vuzov [Training of professional manual skills and assessment of their level of formation among students of medical schools]. Vrach - Doctor, 7, 81-83 [in Russian].
Симуляційне навчання повинно проводитися досвідченими фахівцями, штатними інструкторами (викладачами-тренерами, навчальними майстрами), які спільно з практикуючими спеціалістами (експертами) будуть створювати і накопичувати багаж різних сценаріїв, вести методичну роботу, а також спільно з технічними працівниками (техніками та інженерами) розробляти і підтримувати в робочому та безпечному стані засоби навчання (програмне забезпечення, комп’ютери, тренажери, симулятори, фантоми, моделі і професійне обладнання) тощо.

Висновки. Очевидно, що підготовка фахівців, відповідальних за життя і здоров'я людей, у сучасному світі просто не може будуватися без найважливішого симуляційного компонента. Накопичений великий досвід підтверджує ефективність симуляційного навчання.

За кордоном, де ці технології з'явилися раніше, накопичений досвід дозволив створити систему симуляційного навчання, застосування якого покликане істотно підвищити якість, ефективність і безпеку медичної допомоги, що надається населенню.

кова, Н. С. Подчерняева, Л. Б. Шубина // Врач. - 2007. № 7. - С. 81-83.

4. Навчально-інноваційний центр практичної підготовки лікаря, Одеський національний медичний університет. - URL : http://www. onmedu.edu.ua/osvita/navchalnoinnovacijnij-centr-praktichnoi-pidgotovki-likarja/.

5. Вінницький симуляційно-методичний центр. URL : http://anest.vn.ua/?med=sim\&option=menuSim\& id_menu=21.

6. Татур Ю. Г. Компетентность в структуре модели качества подготовки специалиста / Ю. Г. Татур // Высшее образование сегодня. - 2004. - № 3. - С. 20-26.

4. The Educational and Innovation Center for Practical Preparation of the doctors, Odesa National Medical University. - Retrieved from: http://www. onmedu.edu.ua/ osvita/navchalno-innovacijnij-centr-praktichnoi-pidgotovkilikarja/

5. Vinnytsia simulation and methodical center. - Retrieved from: http://anest.vn.ua/?med=sim\&option=menuSim\& id_menu=21.

6. Tatur, Yu.G. (2004). Kompetentnost v strukture modeli kachestva podgotovki spetsialista [Competence in the structure of the specialist training quality model]. Vyssheye obrazovanie segodnya - Higher Education Today, 3, 20-26 [in Russian].

Отримано 20.03.18

Електронна адреса для листування: rector@onmedu.edu.ua 